\title{
Percutaneous ultrasound-guided renal biopsy; A comparison of axial $v s$. sagittal probe location
}

\author{
FARNAZ SHAMSHIRGAR $^{1}$, SEYED MORTEZA BAGHERI ${ }^{2 *}$ \\ ${ }^{1}$ Resident of Radiology, Iran University of Medical Sciences, Tehran, Iran \\ ${ }^{2}$ Department of Radiology, Hasheminejad Kidney Center (HKC), Iran University of Medical Sciences, Tehran, Iran
}

\begin{abstract}
Background. Renal biopsy is an important method for diagnosis of renal parenchymal abnormalities. Here, we compare the effectiveness and complications of percutaneous ultrasoundguided renal biopsy using axial vs. sagittal probe locations.

Methods. In a cross-sectional survey, in 2012, patients with a nephrologist order were biopsied by a radiology resident. Renal biopsy was done on 15 patients using axial (A group) and the same number of biopsies done with sagittal probe location (S group). The two groups were compared in term of the yields and complications of each method.

Results. In the A group, the ratio of glomeruli gathered to the number of obtained samples was significantly higher than in the $\mathrm{S}$ group. Nine patients in the A group (60\%) required only two samplings, whereas $66.7 \%$ in the $\mathrm{S}$ group required more than two attempts. Microscopic hematuria was more common in the A; conversely, gross hematuria was less common in the A group. Meagre hematomas were more frequent in the $\mathrm{S}$ group .When compared with hemoglobin level before biopsy, its level 24 hours after biopsy was similar within groups.

Conclusion. Our study shows that percutaneous ultrasound-guided renal biopsy using axial probe provides better yield with fewer efforts and fewer serious complications.
\end{abstract}

Keywords: Percutaneous renal biopsy, Ultrasound-guided renal biopsy, Ultra-sonography probe location.

\section{INTRODUCTION}

Percutaneous renal biopsy is an important method to diagnose most kidney diseases. This method was first used in 1934 and it has turned into a quite common method. Of all the imaging photos to determine the location of kidney before biopsy, sonography is a safe and easy method. Using the automatic biopsy needle, this can be achieved rather simply today. The ability of guiding the needle to the appropriate location for biopsy depends on the skill of the radiologist. However, the location of sonography probe also plays a major role in revealing the appropriate site. Despite all the advantages, we need to keep in mind that percutaneous renal biopsy also has side effects. These side effects are quite limited including hematoma around the kidney or subcapsular hematoma and do not require medical intervention and will be absorbed naturally within three months $[1,2]$. There are other side effects such as macroscopic hematuria, arteriovenous fistula, aneurysm, acute obstruction of urinary tract by blood clots and ruptured kidney that require medical intervention (such as blood transfusion, or invasive interventions). These com- plications and related post therapeutic side effects may cause another complication such as vascular occlusion, acute obstruction of renal output, renal failure, septicemia or even death $[1,2]$. However, due to the need to achieve final and certain diagnosis in all renal diseases, conducting biopsy seems necessary [3]. For example, in the case of diagnosing the malignancies, it is just through the result of biopsy that the appropriate treatment can be selected. On the other hand, due to low sensitivity and large cases of non-diagnostic samples, percutaneous cytological biopsy is not agreed upon by everyone [4, 5]. Although this method is claimed to have great sensitivity and specificity $[6,7]$, the results of other studies indicate the advantages of surgical methods for sampling to be used in pathology reviews [8]. However, one must keep in mind that imaging guided biopsy has been used only in limited cases to diagnose the renal masses; however, this method can be a good and appropriate choice in studying the small renal masses which are mostly benign. Today, fine needle aspiration (FNA) and needle core biopsy (NCB) are used for sampling. Due to the shortcomings of FNA for interpreting the cell samples acquired, 
most pathologists prefer to use the biopsy samples acquired by NCB method for the accurate interpretation of the tissue structure [9].

The standard method is to conduct biopsy under local anesthesia and through the lower bridge of the kidney while the patient is lying on his abdomen [10]. In this position, the kidney gets closer to the posterior abdominal wall and it will be much easier to access it. Medical experiences and the studies conducted over the past 2 decades [10, $11,12]$ have proven this method to be suitable for most of the patients. This method, however, is not without limitations. As the body mass and fat in the patient increases, it gets harder for the researcher and the doctor to see the kidney and diagnose the exact location of the biopsy site [13, 14]. Although the ability of sonographist in placing the sonography probe and changing the viewing angle and the angle of needle while entering the kidney and the state of the patient during biopsy play major roles in determining the final results, no research has ever been done to study the influence of how probe is placed on the yield and facilitation of the sampling methods. Thus, we decided to conduct a cross-sectional study in order to evaluate the relative advantage of applying sonography probe in both the axial and sagittal methods and investigate the prevalence of biopsy side effects in each method.

\section{MATERIAL AND METHODS}

The present study was conducted after the consent of the ethics committee of Tehran University of Medical Sciences had been gained. The patients who were directed to the radiology center of Shahihd Hasheminejad Hospital for sonography-guided renal biopsy in 2012 were selected for a prospective study. Sonography was conducted using SIEMENS ACUSON X500 device and CURVE 2-6 MHz probe. The method for applying sonography probe (in the axial or sagittal position) for the patients was selected randomly. The samples were taken by a radiology senior assistant under the supervision of a radiologist. Prior to biopsy, coagulation tests and counting of blood cells was done and appropriate measures were taken to correct any existing disorders. For sonography-guided biopsy, the length of the kidney and thickness of renal parenchyma on both sides was measured. Biopsy was conducted through the lower pole of the kidney which was easier to access.
While conducting the biopsy, care was taken to let the needle tip to move the junction of renal parenchyma and renal sinus.

Cases whose kidneys were smaller than $9 \mathrm{~cm}$ or the thickness of their cortex was less than $1 \mathrm{~cm}$ or did not agree to take part in the research were excluded from the study. In the other cases, the patients lay on their abdomen and ultrasonography was conducted by placing the probe in the axial or sagittal position in order to select the appropriate site for biopsy. After choosing the appropriate site, the site was disinfected using Betadine $10 \%$, and Lidocaine $2 \%$ was injected in the path or the spinal needle up to the vicinity of renal capsule surface in order to achieve local anesthesia. Then, 16 gauge TSK semi-automatic needle was used for sampling and after pulling the needle out, the patient used his hand to press on the site of incision to stop the bleeding.

After each sampling, the resulting tissue was sent to the pathology unit and if the number of glomerules was not enough in the initial studies, a second sampling was conducted. This procedure was repeated until there were enough glomerules for diagnosis, of course if there were no biopsy side effects. At the end of the procedure, the patient was under supervision for 24 hours for hematuria (microscopic or macroscopic) and pain and, hemoglobin levels were checked 6 hours after the biopsy. All the patients were checked again for formation or development of hematoma around their kidneys and underwent ultrasonography 24 hours after biopsy.

The sampling continued until there were 15 cases in each group by a radiologist with the same method. The information about each patient were recorded in a special questionnaire form covering variables such as age, gender, frequency of sampling, the number of Glomerules in pathological analysis, patient's satisfaction, the physician's satisfaction, length of sampling, the resulting side effects (microscopic and macroscopic hematuria, early and late hematoma formation), the volume of hematoma immediately and 24 hours after biopsy, and the level of hemoglobin 6 hours after biopsy.

\section{Statistical analysis}

The resulting information was analyzed using SPSS v.19 in Windows ${ }^{\mathrm{TM}}$. Further to the descriptive analysis of the results, Chi Square was used to assess the association between qualitative variables, and t-test was used to compare quantitative variables. The significance level was set to $\mathrm{P}<0.05$. 


\section{RESULTS}

The present research studied 30 patients who were directed to the center for sonography-guided biopsy. The patients included 15 male and 15 female participants. The average age among women was $39 \pm 12.15$ (ranging from 17 to 65 years old), while the average age of men was $40 \pm 11.01$ (ranging from 22 to 64 years old). The average age of all the participants was $39.5 \pm 11.41$ years old.

The majority of the participants (nearly onethird of them) were in the third decade of their life . $60 \%$ of patients were women. There was only one female patient younger than 20 who had resorted to the center for sonography-guided renal biopsy.

The present study revealed the fact that axial probe biopsy resulted in a higher number of Glomerules in the tissue and the ratio of Glomerules to the times of sampling was 11.35, while this ratio in sagittal probe sampling was 7.36 $(\mathrm{P}=0.000)$. The majority of cases $(60 \%)$ required only two sonography-guided biopsies using axial probe, while $33 \%$ required 3 and $6.7 \%$ required 4 sonography-guided biopsies. The following frequencies were attained with sagittal probe: $33.3 \%$ required 2 biopsies, $40 \%$ required 3 biopsies, $26.7 \%$ required 4 or 5 biopsies. However, no statistically significant difference was observed between the frequency of biopsies and in terms of using axial or sagittal probes.

On the other hand, the average biopsy time in the axial probe method was much shorter than the sagittal probe method with the latter being 15.2 minutes and the former being 10.6 minutes $(\mathrm{P}=0.002)$.

The patients reported their pain based on the special chart prepared for this purpose with 0 indicating the least pain and 10 indicating an intolerable pain. Pain levels below 4 were reported as mild pain, levels 4 to 7 were reported as having average pain and 7 had intense pain. As the results indicate, many patients $(46.7 \%)$ had average pain and this level among those who had used axial probe was $53.3 \%$ and among those who had used sagittal probe was $40 \%$. Using axial probe, $40 \%$ had mild pain and only $6.7 \%$ had severe pain, while these values were $20 \%$ and $40 \%$ respectively among those who had used the sagittal probe. However, these differences were not statistically significant $(\mathrm{P}=0.111)$.

The satisfaction levels of the patients were defined in terms of the correspondence between the patient's presupposition of biopsy and what had really happened to him. The following results were reported about patients' satisfaction: total satisfaction in the cases where the procedure was in full accordance with what the patient expected, average for the cases where the level of pain or the length of the procedure was more than what was expected but did not bother the patient, and low for the cases where the level of pain or the length of the procedure bothered the patient. Based on this, the majority of the patients $(70 \%)$ had low satisfaction with the way the procedure was conducted; however, the level of dissatisfaction among those who had used sagittal probe was even greater. Among those who had used sagittal probe, $86.7 \%$ had low satisfaction and 13.3 had average satisfaction. These values in the case of using axial probe were $53.3 \%$ and $46.7 \%$ respectively. However, this difference was not statistically significant $(\mathrm{P}=0.109)$. The important point that needs to be taken into consideration is that neither of the methods could achieve total satisfaction with patients.

The following results were reported for doctors' satisfaction in terms of sampling simplicity and less frequency of sampling: total satisfaction for the cases where the procedure progressed simply, average satisfaction for the cases that the procedure was not simple, but the sufficient amount of tissue was obtained with at least 3 biopsies, and low satisfaction for the cases that only little amounts of tissue were obtained for pathology despite the long time spent for the process and multiple times of biopsy. Based on the results, the doctors' satisfaction levels were mostly low $(43.3 \%)$ or average $(46.7 \%)$ and it was only in $10 \%$ of the cases where the doctors were fully satisfied with the method used for biopsy. The levels of dissatisfaction in the cases where sagittal probe was used were higher with $46.7 \%$ of the doctors having little satisfaction, $40 \%$ of them having average satisfaction and $13.3 \%$ being fully satisfied with the process. These values in the case of using axial probe were $40 \%, 53.3 \%$ and $6.7 \%$ respectively. However, these differences were not statistically significant $(\mathrm{P}=0.772)$.

The side effects of percutaneous renal biopsy in this study were microscopic hematuria (70\%), gross $(10 \%)$ and formation of perinephric or subcapsular hematoma (46.7\%). No hemoglobin drop was observed in the patients. Using axial probe resulted in microscopic hematuria and gross hematuria in $80 \%$ and $6.7 \%$ of the cases, respectively. 
However, using sagittal probe resulted in microscopic hematuria and gross hematuria in $60 \%$ and $13.3 \%$ of the cases respectively. $26.7 \%$ of the patients who had used sagittal probe showed no signs of hematuria and this value among the cases who had used axial probe was $13.3 \%$. These differences were not statistically significant $(\mathrm{P}=0.427)$.

Among those who had used sagittal probe and those who had utilized axial probe, early hematoma was observed in $8(53.3 \%)$ and 5 $(33.3 \%)$ cases, respectively. In the follow-up which was conducted 24 hours after biopsy, no new cases of hematoma were observed among any of the patients. However, these differences were not statistically significant $(\mathrm{P}=0.269)$.

Among 5 cases of hematoma with axial probe, the average volume of hematoma was $13.6 \pm$
$3.5 \mathrm{cc}$ with the least and the highest levels of hematoma being 10 and $18 \mathrm{cc}$, respectively. Among the 8 cases of hematoma with sagittal probe, the average volume of hematoma was $17.25 \pm$ $9.49 \mathrm{cc}$ with the least and the highest levels of hematoma being 7 and $35 \mathrm{cc}$, respectively. However, these differences were not statistically significant $(\mathrm{P}=0.179)$.

This study indicated no difference between the average hemoglobin level due to the formation of hematoma or following hematuria and hemoglobin measurement before biopsy in either of the methods. Table 1 represents the frequency of biopsy side effects in terms of the sampling method.

As more than just one side effect was observed among the patients in some cases, the terms "total" means the number of patients studied in each group.

Table 1

The frequency of biopsy side effects in terms of the sampling method using axial or sagittal method

\begin{tabular}{|l|c|c|c|}
\hline Biopsy side effect & Usiopsy method & Using axial probe & Total \\
\hline Gross hematuria & & & $3(10 \%)$ \\
\hline Microscopic hematuria & $2(13.3 \%)$ & $1(6.7 \%)$ & $21(70 \%)$ \\
\hline Hematoma around the kidney (early) & $9(60 \%)$ & $12(80 \%)$ & $17(56.7 \%)$ \\
\hline No side effects & $7(46.7 \%)$ & $10(66.7 \%)$ & $8(53.3 \%)$ \\
\hline Total & $5(33.3 \%)$ & $3(20 \%)$ & $30(100 \%)$ \\
\hline
\end{tabular}

\section{DISCUSSION}

The present research seeks to comparatively study the advantages of sonography-guided biopsy using sagittal and axial probe methods. In this research, biopsy was conducted using TSK, 16 gauge semi-automatic needle without aspiration. In each case, biopsy was repeated as many times as necessary in order to achieve the desired amount of the tissue. The average frequencies of biopsy in axial probe and sagittal probe methods were 2.47 and 3 times respectively with the total average being 2.73. As other studies indicate, sampling twice will be sufficient in $97 \%$ of the cases for pathology review $[15,16,17]$. As the majority of the researches indicate, at least 2 biopsies are required to obtain the sufficient amount of the tissue required in renal biopsy [18]. The great frequency of biopsy in the present study compared to other researches can be justified by the influence of selecting the needle type for biopsy and also biopsy by radiology assistant and repeating the procedure of sampling until the pathology technician decides that the number of Glomerules for pathology review is enough. The sampling was repeated twice in $60 \%$ of the cases who had used the axial probe and in $33.3 \%$ of the cases who had used the sagittal probe. Although all the samples in this research were gained using TSK, 16 gauge semiautomatic needle, the sonographist skill in providing the appropriate sample with less times of sampling seems to be particularly important. In the cases where the sonographist is not so skillful, 3 times biopsy using the axial probe can provide us with the appropriate sample for pathology review in 93.3\% of the cases. However, CT scan-guided renal biopsy especially in the cases suspicious of focal diseases which provides us with the enough number of Glomerules for the certain diagnosis eliminates any needs for repeating the biopsy [19].

The quality of the samples taken by traditional needles is not so suitable in such a way that an average of 17.6 healthy Glomerules are found in these samples, while the average number of healthy Glomerules in the samples taken by NCB method is 11.5 [20]. Other studies privilege CT scan for 
percutaneous renal biopsy in such a way that the average number of the Glomerules in the samples taken through sonography-guided and CT scanguided methods were $10.28 \pm 6.85$ and $23.34 \pm$ 13.24 respectively [19]. The ratio of the Glomerules to frequency of biopsy using axial probe was 11.35 in the present research which is nearly equal to the results of previous studies, while this number in sagittal probe sampling was 7.36. The sagittal probe biopsy seems to be of poor quality as it does not represent an appropriate image of the site. Other studies indicate that the average numbers of Glomerules are $15.62 \pm 5.26$ and $13.7 \pm 7.38$ when biopsy is done by the nephrologists and radiologists respectively [18]. Although this level is more than the results attained through the analysis of the present and other researches, radiologists seem to be less successful in obtaining the enough tissue. This can be attributed to the great care they take so as not to harm the renal tissue.

The side effects of percutaneous renal biopsy in this study were microscopic hematuria $(70 \%)$, gross $(10 \%)$ and formation of perinephric or subcapsular hematoma $(46.7 \%)$. As the recent studies indicate and due to the high frequency of the side effects caused by vascular damages in common biopsy through the lower bridge with cranial angle, biopsies are better to be conducted with caudal angle [21]. Other researches which have taken into consideration the side effects of renal biopsy show that major side effects have not shown in any of the patients and only minor side effects which did not require medical intervention were observed among $23.5 \%$ of the patients. The most common type of side effect in this disease was hematoma around kidneys without any symptoms which was diagnosed with another sonography 1 to 3 days after renal biopsy. Abdominal pain with hematoma around the kidneys was reported among $1.4 \%$ of the patients and macroscopic hematuria was observed in $4.2 \%$ of the patients 1 to 3 days after biopsy [22]. Another research which compared utilization of biopsy gun and the common method arrived at the conclusion that although the prevalence of minor side effects in traditional biopsy is more (15\% vs. $8 \%$ ), two major side effects were reported for utilizing biopsy gun. However, no cases of major side effects were reported in needle biopsy [20]. But in studying hematuria following renal biopsy with a different size of biopsy needle, the levels of macroscopic hematuria and blood requirement were reported to be $3.9 \%$ and $0.9 \%$. More cases requiring blood transfusion and macroscopic hematuria were reported while using number 14 needle than while using smaller needles. Among the other risk factors of acute renal damages, female gender, average age equal to or older than 40 , and systolic blood pressure higher than $130 \mathrm{mmHg}$ were highlighted [23].

In the present research, microscopic hematuria and gross hematuria were observed among $80 \%$ and $6.7 \%$ of the cases using axial probe. These numbers were $60 \%$ and $13.3 \%$ respectively while using sagittal probe. The early hematoma was observed in $53 \%$ of the cases with sagittal probe (with the average volume of the hematoma being $17.25 \pm 9.49 \mathrm{cc}$ ) and in $33 \%$ of the cases with axial probe (with the average volume of the hematoma being $13.6 \pm 3.5 \mathrm{cc}$ ). However, the follow-up examinations 24 hours after the operation showed to hematoma volume rise or a new case of hematoma in any patient.

The average hemoglobin level due to the formation of hematoma or following hematuria showed no difference with the hemoglobin levels before biopsy in any of those methods. As the side effects were never serious enough to cause hemoglobin drop in the patient or demand medical intervention, the cause of most complaints reported in this research seems to be checking all the patients in terms of this variable and it has nothing to do with the method of biopsy in this or other studies. It should also be remembered that choosing the biopsy needle can also play a major role in causing the side effects. For example, major side effects in End-Cut needle biopsy are 4.8 times less than Tru-Cut needle biopsy [17]. Other studies indicate the positive influence of sonographyguided biopsy in reducing the major side effects. For example, big hematoma which requires surgery or blood transfusion was not observed in any cases of sonography-guided biopsy, while $11 \%$ of those who undergo blind biopsy are exposed to this side effect [24]. As other studies indicate, less side effects are observed among those undergoing biopsy by nephrologists than those patients undergoing biopsy by a radiologist.

\section{Significance of findings}

In those cases where the individual lacks sufficient skill in operating sonography device for biopsy, placing sonography probe inside the axial section may result in more successful cases in biopsy. Our study had a limitation that is a small number of patients. 


\section{CONCLUSION}

The influence of the individual in charge of biopsy plays a major role in gaining the appropriate insight for ideal biopsy and preventing the major side effects such as hematuria and hematoma around the kidney.

Conflict of interest. The authors confirm that this article content has no conflict of interest.

Introducere. Biopsia renală este o metodă importantă pentru diagnosticul modificărilor renale parenchimatoase. In acest studiu sunt comparate omplicațiile şi eficiența biopsiei renale ghidate ecografic folosind aplicarea sondei sagital sau axial.

Materiale si metode. A fost realizat un studiu transversal în 2012 unde 15 pacienți au fost biopsiați folosind plasarea sondei axial (grupul A) şi 15 pacienți au fost biopsiați folosind plasarea sondei ecografice sagital (grupul S). Grupurile au fost ulterior comparate din punctul de vedere al complicatiilor.

Rezultate. In grupul A numărul de glomeruli raportat la proba obținută a fost semnificativ statistic mai mare comparativ cu grupul S. 9 pacienți din grupul A (60\%) au necesitat doar două încercări pentru obținerea probei comparativ cu $66.7 \%$ din pacienții din grupul $S$ unde a fost nevoie de mai mult de două încercări. Hematuria microscopică a fost mai frecventă în grupul A însă hematuria macroscopică a fost mai frecventă în grupul $S$.

Hematoamele au fost mai frecvente în grupul S. Nivelurile hemoglobinei la 24 de ore după puncție erau similare între cele două grupuri.

Concluzii. Studiul arată faptul că obținerea probelor bioptice folosind plasarea axială a sondei de ecografie se însoțeşte de mai puține reacții adverse.

Correspondence to: Seyed Morteza Bagheri, Department of Radiology, Hasheminejad Kidney Center (HKC), Iran University of Medical Sciences, Tehran, Iran, Tel: 00989121150807

E-mail:smb553@yahoo.com

\section{REFERENCES}

1. MANNO C, STRIPPOLI GF, ARNESANO L. Predictors of bleeding complications in percutaneous ultrasound-guided renal biopsy. Kidney Int 2004; 66:1570-7.

2. WHITTIER WL, KORBET SM. Timing of complications in percutaneous renal biopsy. J Am Soc Nephrol 2004; 15:142-7.

3. TAKASHI M, TAKAGI Y, SAKATA T, et al., Clinicopathological characteristics of small renal carcinomas. Int Urol Nephrol. 1994; 26:621-629.

4. CAMPBELL SC, NOVICK AC, HERTS B, et al., Prospective evaluation of fine needle aspiration of small, solid renal masses: accuracy and morbidity. Urology. 1997; 50:25-29.

5. BRIERLY RD, THOMAS PJ, HARRISON NW, et al., Evaluation of fineneedle aspiration cytology for renal masses. BJU Int. 2000; 85:14-18.

6. HARA I, MIYAKE H, HARA S, et al., Role of percutaneous image-guided biopsy in the evaluation of renal masses. Urol Int. 2001; 67:199-202.

7. CAOILI EM, BUDE RO, HIGGINS EJ, et al., Evaluation of sonographically guided percutaneous core biopsy of renal masses. AJR Am J Roentgenol. 2002; 179:373-378.

8. NEUZILLET Y, LECHEVALLIER E, ANDRE M, et al., Accuracy and clinical role of fine needle percutaneous biopsy with computerized tomography guidance of small (less than $4.0 \mathrm{~cm}$ ) renal masses. J Urol. 2004; 171:1802-1805.

9. NYMAN RS, CAPPELEN-SMITH J, BRISMAR J, et al., Yield and complications in ultrasound guided biopsy of abdominal lesions. Comparison of fine needle aspiration biopsy and 1.2-mm needle core biopsy using an automated gun. Acta Radiol 1995; 36:485-90.

10. HERGESELL O, FELTEN H, ANDRASSY K, et al., Safety of ultrasound-guided percutaneous renal biopsy-retrospective analysis of 1090 consecutive cases. Nephrol Dial Transplant 1998; 13: 975-977.

11. MEOLA M, BARSOTTI G, CUPISTI A, et al., Free-hand ultrasound-guided renal biopsy: report of 650 consecutive cases. Nephron 1994; 67: 425-430.

12. MANNO C, STRIPPOLI GFM, ARNESANO L, et al., Predictors of bleeding complications in percutaneous ultrasound-guided renal biopsy. Kidney Int 2004; 66: 1570-1577. 
13. STILES KP, YUAN CM, CHUNG EM, et al., Renal biopsy in high-risk patients with medical diseases of the kidney. Am J Kidney Dis 2000; 36: 419-433.

14. FINE DM, AREPALLY A, HOFMANN LV, et al., Diagnostic utility and safety of transjugular kidney biopsy in the obese patient. Nephrol Dial Transplant 2004; 19: 1798-1802

15. CRISTALLINI EG, PAGANELLI C, BOLIS GB. Role of fine-needle aspiration biopsy in the assessment of renal masses. Diagn Cytopathol. 1991; 7:32-35.

16. JUUL N, TORP-PETERSON S, GRONVALL F, et al., Ultrasonically guided fine needle aspiration biopsy of renal masses. J Urol. 1985; 133:579-581.

17. CONSTANTIN A, BRISSON ML, KWAN J, PROULX F. Percutaneous US-guided Renal Biopsy: A Retrospective Study Comparing the 16-gauge End-cut and 14-gauge Side-notch Needles. J Vasc Interv Radiol 2010; 21:357-361.

18. YESUDAS SS, GEORGY NK, MANICKAM S, et al., Percutaneous real-time ultrasound-guided renal biopsy performed solely by nephrologists: A case series. Indian J Nephrol. 2010; 20(3):137-41.

19. MUKHTAR KN, MAHMOOD SN, UMAIR SF. CT guided percutaneous renal biopsy versus ultrasound guided for obtaining adequate tissue. J Pak Med Assoc. 2012; 62(9)_880-882.

20. KUMAR A, MITCHELL MJ, AGGARWAL S, FRASER DB, TRILLO AA. Ultrasonography-directed native renal biopsy: comparison of an automated biopsy device with a needle system. Can Assoc Radiol J. 1992; 43(5):359-63.

21. CHISHTI I, BURHAN D, HAIDER Z, SAJJAD Z. Renal biopsy: ultrasound guided renal biopsy using a caudal angulated needle path to improve cortical sampling. Pakistan journal of radiology. 2008; 18(3): 74-76.

22. SKALOVA S, REJTAR P. Safety profile of paediatric percutaneous ultrasonography-guided renal biopsies. Singapore Med J 2010; 51(6): 481-483.

23. CORAPI KM, CHEN JL, BALK EM, GORDON CE. Bleeding complications of native kidney biopsy: a systematic review and meta-analysis. Am J Kidney Dis. 2012; 60(1):62-73.

24. MAYA ID, MADDELA P, BARKER J, ALLON M. Percutaneous Renal Biopsy: Comparison of Blind and Real-Time Ultrasound-Guided Technique. Seminars in Dialysis. 2007; 20(4): 355-358.

Received October 22, 2016 